\title{
Wound healing activity in rabbits and antimicrobial activity of Hibiscus hirtus ethanolic extract
}

\author{
Kakaraparthy Ravishankar¹, Garlanka Venkata Naga Kiranmayi ${ }^{*}$, Yejella Rajendra Prasad ${ }^{2}$, \\ Lankadi Devi ${ }^{1}$
}

\author{
${ }^{1}$ Aditya College of Pharmacy, Aditya Nagar, A.D.B.Road, Surampalem, Andhra Pradesh, India, ${ }^{2}$ University College of \\ Pharmaceutical Sciences, Andhra University, Visakhapatnam Andhra Pradesh, India
}

\begin{abstract}
Generally, Plants have immense potential in the wounds management and treatment.In Chinese herbology, Hibiscus plant is a potent herb and have a good medicinal values but not scientifically approached. The present study aims to investigate the wound healing and antimicrobial activity of ethanolic extract of Hibiscus hirtus Linn. $(H H)$. Wound healing activity was carried out by excision, incision and burn wound models. Antimicrobial activity was determined by cup plate method. Healing rate was assessed from the rate of wound contraction, epithelialization rate, tensile strength, hexosamine and hydroxyproline content. From the obtained results, it was indicated that the wound contraction and increased tensile strength of Hibiscus hirtus extract exhibits potent wound healing capacity. Hexosamine and hydroxyproline expression were also correlative with the pattern of healing observed. Histological observation indicates that the wounds treated with Hibiscus hirtus extract and povidone iodine have reduced scar formation and enhances fibroblast proliferation, angiogenesis, keratinization and epithelialization. The Hibiscus hirtus extract has excellent antimicrobial activity against the various organisms. Wound healing activity of our ethanolic extract of Hibiscus hirtus has shown the good effect which has proved by different physical, histological, biochemical parameters. Significant antimicrobial activity shown may be due to major active constituents present in plant.
\end{abstract}

Keywords: Hibiscus hirtus/wound healing activity/antimicrobial activity. Medicinal plants.

\section{INTRODUCTION}

Plants have immense potential in the wounds management and treatment. To treat various wound injuries and skin disorders, many plants are used as traditional medicines (Swamy et al., 2007; Harish et al., 2008; Sharath et al., 2010; Lingaraju et al., 2012). Wounds are physical injuries that lead to an opening or breaking of the skin. Wound healing processes consist of integrated cellular and biochemical cascades leading to reestablishment of structural and functional integrity of the damaged tissue (Boateng et al., 2008) The injured tissues repair occurs as a sequence of events, which consists of inflammation, proliferation, and migration of different cell types (Sidhu et al., 1999). The inflammatory stage begins after an injury, initially with vasoconstriction that

\footnotetext{
*Correspondence: G.V.N. Kiranmayi. Aditya College Of Pharmacy, Surampalem, East Godavari District, Andhra Pradesh, India, 533437. Telephone no.: 09989076825. E-mail: kiranmayi54@yahoo.com
}

causes homeostasis and releases various mediators of inflammation. The proliferative phase mainly consists of a proliferation of granulation tissue formed by fibroblast and the angiogenesis process. Reformulations and improvement in the components of the collagen fiber that increases the tensile strength are characteristics of remodeling stage (Varoglu et al., 2010). Poor perfusion or oxygenation, Repeated trauma, and excessive inflammation are the factors that are responsible for the causation and perpetuation of the chronicity of wounds (Harding, Moore, Phillips, 2005). Various growth factors such as transforming growth factor beta (TGF- $\beta$ ), platelet activation factor (PAF), epidermal growth factor (EGF), and platelet-derived growth factors (PDGF) seem to be necessary for the initiation and promotion of wound healing (Menke et al.,2007)

The plant constituents are having better compatibility with the human body as they are a part of the physiological function of living flora (Kamboj, 2000). Many Scientists are looking towards the Indian traditional system of medicineThe present treatment for the wounds includes 
the application of silver products, steroids, advanced skin substitutes and dressings, growth factor, negative pressure wound devices, and hyperbaric oxygen (Murphy, Evans, 2012). In the management and treatment of wounds, plants have immense potential. Several plants have been experimentally used to treat skin disorders and wound injuries as traditional medicines (Swamy et al., 2007; Harish et al., 2008; Sharath et al., 2010).

Hibiscus genus is the flowering plants in the mallow family, Malvaceae. The genus contains several hundred species that are native to warm-temperate, subtropical, tropical regions throughout the world and is quite large. Hibiscus plant has a number of medical uses in Chinese Herbology. Their research indicates some potential in cosmetic skin care; for example, an extract from the flowers of Hibiscus plant has been shown to function as an anti-solar agent by absorbing ultraviolet radiation (Sidram, Lokapure, Kalyane, 2011).

In the Indian traditional system of medicine, Ayurveda, Hibiscus, especially white Hibiscus and red Hibiscus are considered to have medicinal properties. The roots are used to make various concoctions believed to cure ailments such as cough, hair loss or hair graying. The leaves and flowers are ground into a fine paste with a little water, and the resulting lathery paste is used as a shampoo plus conditioner. A previous animal study demonstrated the effects of the Hibiscus plant extract on atherosclerosis in rabbits. Notably, a reduction in triglyceride, cholesterol, and low density lipoprotein was observed in rabbits consuming a high cholesterol diet (HCD) in addition to Hibiscus plant extract compared to rabbits only fed HCD, suggesting a beneficial effect (Chen, Hsu, Wang, 2003). Furthermore, the Hibiscus seed is abundant in phytosterol and tocopherol, plant forms of cholesterol that has antioxidant and LDL cholesterol lowering effects (Mohamed et al., 2007). Based on the literature review,so far no work has been carried out in Hibiscus hirtus Linn. $(H H)$. Antimicrobial and wound healing activities have been reported in some species of the genus Hibiscus.

Therefore the present investigation carried out an indepth study regard the $H$. hirtus ethanolic extract wound healing activities using incision, excision, and burn wound models and evaluated its antimicrobial potential against pathogenic microorganism.

\section{MATERIAL AND METHODS}

\section{Collection of plant}

The whole plant of $H H$ was collected near the Pithapuram, Andhrapradesh, India which is located at
India country in the Castles place category with the gps coordinates of $17^{\circ} 6^{\prime} 44.7372$ " $\mathrm{N}$ and $82^{\circ} 15^{\prime} 10.4364^{\prime \prime} \mathrm{E}$ during November 2014. The plant was authenticated by Dr.S.B.Padal, Associate Professor, Botany Department, Andhra University and given a voucher specimen number as 22205 .

\section{Preparation of ethanolic extract of $\mathrm{HH}$}

The freshly collected whole plants of $H H$ were cleared of dirt and dried under shade for about 20 days and the grindered into powder using a mechanical grinder. The powder was extracted with $95 \%$ ethanol (was used for extraction as many polar and non polar compounds can be extracted from the ethanol ) for 3 days, followed by hot percolation for $3 \mathrm{hrs}$. Then it was filtered and distilled at $80^{\circ} \mathrm{C}$. Then it was transferred into the previously weighed empty china dish and evaporated to get a ethanolic extract and kept in anhydrous calcium chloride containing desiccator. The percentage yield of the extract was calculated (Khandelwal, 2008).

\section{Preparation of HH ointment}

Based on literature review on other Hibiscus species (Bhaskar, Nithya, 2012) the extract was prepared with two concentrations of extract containing ointment $(10 \%$ and $20 \% \mathrm{w} / \mathrm{w})$. The $10 \%$ ointment of $H H$ consists of plant extract $2.5 \mathrm{~g}$ and $22.5 \mathrm{~g}$ of ointment base(white bees wax $1.5 \mathrm{gm}$ and white soft paraffin $21.0 \mathrm{~g}$ ). The $20 \%$ ointment of $H H$ consists of plant extract $5 \mathrm{~g}$, and 20gm.of ointment base (white bees wax $1.5 \mathrm{~g}$ and white soft paraffin $21.0 \mathrm{~g})$

\section{Preliminary phytochemical testing}

Preliminary phytochemical screening of $H H$ extract was done to test the presence of the active chemical constituents such as alkaloids, flavonoids, tannins, phenolic compounds, saponins, fixed oils and fats (Khandelwal, 2004).

\section{Quantitative phytochemical testing}

Etimation of phenolic contents

The phenolic contents of ethanolic extract of $H H$ were determined by using the method Folin-ciocalteu (Singleton, Orthofer, Lamuela-Raventós, 1999). An extract of $0.5 \mathrm{~mL}$ was mixed with $3 \mathrm{~mL}$ Folin-ciocalteu reagent $(1: 10 \mathrm{v} / \mathrm{v})$. Allow it for $5 \mathrm{~min}$, and then add $4 \mathrm{~mL}$ of $(20 \% \mathrm{w} / \mathrm{v})$ of sodium carbonate solution. The tubes were kept aside for 15 minutes at $30{ }^{\circ} \mathrm{C}$ temperature for colour development. Read at $765 \mathrm{~nm}$ by spectrophotometer. 
Phenolic content were estimated from the calibration curve using standard gallic acid in methanol and the results were expressed as gallic acid equivalent $\mathrm{mg} / 100 \mathrm{mg}$ dry weight of extract.

Estimation of total flavanoids

Total flavonoid contents of $H H$ ethanolic extract was determined by aluminium chloride method (Chang et al., 2002). To $0.6 \mathrm{~mL}$ of the extract, add $1.8 \mathrm{~mL}$ of methanol, $0.1 \mathrm{~mL}$ of $10 \%$ aluminium chloride, $0.1 \mathrm{~mL}$ of $1 \mathrm{M}$ sodium acetate, $3 \mathrm{~mL}$ of distilled water and left at $30{ }^{\circ} \mathrm{C}$ temperature. Note the absorbance after $30 \mathrm{~min}$ at $415 \mathrm{~nm}$. Total flavanoids were estimated from the calibration curve using standard quercetin in methanol and the results were expressed as quercetin equivalent $\mathrm{mg} / 100 \mathrm{mg}$ dry weight of extract.

\section{Estimation of total anthocyanin}

Total anthocyanin content (TAC) of freeze-dried extract was determined using the method described by (Česonienè et al., 2012). 10 mg of freeze-dried extract was mixed in $5 \mathrm{~mL}$ of methanol acidified with trifluoroacetic acid $0.1 \%(\mathrm{v} / \mathrm{v})$. Aliquots of the extracts were taken in a $10 \mathrm{~mL}$ glass tube and adjust to a volume of $3 \mathrm{~mL}$ with methanol acidified with trifluoroacetic acid (TFA) and the absorbance was measured at $530 \mathrm{~nm}$ using a UV/Vis spectrophotometer against the blank sample containing the mixture methanol/TFA $0.1 \%$ without the sample extract, TAC was estimated as cyanidin 3-O-glucoside at $530 \mathrm{~nm}$ using a molar extinction coefficient of $26,900 \mathrm{~L} / \mathrm{mol} /$ $\mathrm{cm})$ and molar mass $(449 \mathrm{~g} / \mathrm{mol})$ and was expressed as $\mathrm{mg}$ cyanidin-3-glucoside (mg Cya3G)/g of freeze-dried extract (g FDE).

\section{Experimental animals}

Rabbits of either sex weighing about $1.8-2.5 \mathrm{~kg}$ were used for the study. Three animals are used in each group in each model and totally 36 animals were used. All the animals are properly caged and maintained under standard pellet diet and water ad libitum, placed in a properly air conditioned room with $12 \mathrm{hrs}$ light and dark cycles. The animal experiments were performed based on the Institutional Ethics Committee (IEC) approval and guidelines REG. No. 1269/a/10/CPCSEA.

\section{Wound healing activity}

Excision, burn and incision wound healing models were used to evaluate the wound healing activity of $\mathrm{HH}$ Animals were divided into four groups of 3 animals $(\mathrm{n}=$ 3) (Aderounmua et al., 2013). Povidone iodine ointment $(5 \% \mathrm{w} / \mathrm{w}$ in oleaginous ointment base (white bees wax 1.5 gm and white soft paraffin $21.0 \mathrm{~g}$ )). is used as standard treatment as it is a well reported antimicrobial agent and is used to prevent secondary wound infections (Khan et al., 2015).

Incision wound model

One parallel $6 \mathrm{~cm}$ paravertebral incisions were made through the full thickness of the skin, $1 \mathrm{~cm}$ lateral to the mid line of the vertebral column after giving anesthesia (Agarwal et al., 2009). The wound was closed with interrupted sutures $1 \mathrm{~cm}$ apart with the help of black silk thread and a curved needle (no.11). The sutures removed on the 7th post wounding day. Wound breaking strength (WBS) was measured on the post wounding day in anesthetized rabbits. Standard weights were put slowly and steadily into the S-shaped hook. A gradual increase in weight was transmitted to the wound side hook apart the wound edges. As and when the wound was just opened up, the weight was stopped and noted. Three readings for a given incision wound were recorded and the entire procedure was repeated again. The average reading of the group was taken as an individual value of breaking strength. Average value indicates the breaking strength for respective group.

\section{Excision wound model}

Rabbits were anesthetized with lignocaine and a wound was made in an area about $500 \mathrm{~mm}^{2}$. Full thickness of the marked skin was then cut carefully. Wounds were traced on $1 \mathrm{~mm}^{2}$ graph paper, initially on the first day of wounding and up to at a gap period of 4 days till $12^{\text {th }}$ day. Then on alternate days healing was complete. Changes in the area of wound were measured periodically and the rate of contraction of the wound was calculated as given in the formula below

$$
\text { Percentage Wound Contraction }=100-\left[\frac{\text { Final diameter }(\mathrm{cm}) \times 100}{\text { initial diameter }(\mathrm{cm})}\right]
$$

Significance in wound healing of the test treated groups is derived by comparing the wound area healed on respective days with the negative control groups. The period of epithelialization was recorded (Nakae, Inaba, 2000)

\section{Burn wound model}

Partial thickness of burn wounds were inflicted on overnight in starved animals under lignocaine anesthesia by pouring the hot molten wax $(2 \mathrm{~g})$ at $80^{\circ} \mathrm{C}$. The wax was poured on the animal shaven area through a cylinder of $300 \mathrm{~mm}^{2}$ circular opening. The wax gets to remain on the 
skin till it gets solidified. Immediately after the injury and on subsequent days, the drug or base was applied topically as mentioned (Rashed, Afifi, Disi, 2003).

Percentage Wound helaing $=100-\left[\frac{\text { Final diameter }(\mathrm{cm}) \times 100}{\text { initial diameter }(\mathrm{cm})}\right]$

Biophysical parameters

In the excision wound model the rate of wound contraction was determined as a percentage reduction of the wound size and the surface area was measured on the 0th, 3rd, 6th, 9th, 12th, 15th, 18th and 21 st post-wounding days by measuring the wound on a transparent graph sheet. The period of epithelialization was also noted (Ghosh et $a l .$, 2012). The degree of wound healing is represented by tensile strength of the wound. It describes how much the repaired tissue resists to breaking under tension and may indicate the quality of repaired tissue. The incision wound tissues tensile strength was measured on the 10th day by Lee's method after the sutures removal on the 8th post-wound day (Lee, 1968).

Biochemical parameters

A piece of skin from the healed wound area was collected on day 4,8 and 16 of the post surgery of excision, and analyzed for hydroxyproline content, which is a basic constituent of collagen. Tissues were dried in the hot air oven to constant weight at $60-70^{\circ} \mathrm{C}$ and were hydrolyzed in $6 \mathrm{~N} \mathrm{HCl}$ at $130{ }^{\circ} \mathrm{C}$ for $4 \mathrm{~h}$ in a sealed tube. The hydrolysate was neutralized to $\mathrm{pH} 7.0$ and was subjected to chloramine $\mathrm{T}$ oxidation for $20 \mathrm{~min}$, by addition of $0.4 \mathrm{M}$ per chloric acid the reaction was terminated and color was developed with the help of ehrlich reagent at $60{ }^{\circ} \mathrm{C}$ (Woessner, 1961) and measured at $557 \mathrm{~nm}$ using UV/Vis spectrophotometer following a method mentioned by Johansen with minor modifications (Johansen, Marshall, Neuberger, 1960).

Histopathology

Deep granulation tissues from the implanted tube and the cross-sectional full-thickness skin specimens were collected on the 10th day for the histopathological alterations. The samples were kept in $10 \%$ buffered formalin, processed, blocked with paraffin, then sectioned into $5 \mu \mathrm{m}$ sections, and stained with hematoxylin and eosin.

\section{Microbial cultures}

These were procured from Microbes Speciality Lab Danavaipeta, Rajahmundry, East Godavari District 533103, Andhra Pradesh, India are aseptically maintained in our laboratory. The gram positive bacteria are
Staphylococcus aureus (ATCCBAA 1026), Bacillus subtilis (ATCC 11774) and Staphylcoccuswerneri (ATCC 27836). The gram negative bacteria used in the study are Eschereria coli (ATCC 10536), Klebisella pneumonia (ATCC 33495), Pseudomonas aurgenosa (ATCC 10662), Pseudomonas putida (ATCC 700007) and Proteus mirabilis (ATCC 14153). The fungal strain used is Candida albicans (ATCC 10231).

\section{Antimicrobial activity}

The antimicrobial screening is based on measuring the diameters of the zones of inhibition around the cylindrical cups incubated with different concentrations of ethanolic extracts of the $H H$ For this sabouraud dextrose agar plate (SDA) seeded with microbial cultures were used. A sterile borer was used to prepare cups of $6 \mathrm{~mm}$ diameter in the agar medium spread with the micro-organisms and $0.1 \mathrm{~mL}$ of inoculum was spread on the agar plate by spread plate technique. $50 \mu \mathrm{L}$ ethanolic extracts concentration of $50,100,150 \mathrm{mg} / \mathrm{mL}$ dissolved in DMSO were filled in the wells. For antibacterial and antifungal activity, gentamycin $(25 \mu \mathrm{g} / \mathrm{mL})$ and flucanozole $(25 \mu \mathrm{g} / \mathrm{mL})$ were used as standard drugs. All the plates were kept in a refrigerator at 2 to $8{ }^{\circ} \mathrm{C}$ for a period of $2 \mathrm{~h}$ for effective diffusion of test compounds and standards. Later, they were incubated at $37^{\circ} \mathrm{C}$ for $24 \mathrm{~h}$. The assay was carried out in triplicate. The diameter of the zone of inhibition was measured and recorded (Indian Pharmacopoeia, 1996).

MIC was determined by the microbroth dilution method. In each well of microtiter plate, specifically $0.1 \mathrm{~mL}$ of standardized inoculums of bacteria $(\mathrm{CFU} / \mathrm{mL})$ was added which was incubated aerobically at $37^{\circ} \mathrm{C}$ for bacterial growth for 18-24 h. MIC means the lowest concentration (highest dilution) of the extract that produced no visible bacterial growth (no turbidity) when compared with that of negative control (Sharma et al., 2007).

\section{Statistical analysis}

Statistical comparison was carried out using either unpaired t-test or one-way analysis of variance (ANOVA) followed by post tests like Dunnett's test for multiple comparisons.

\section{RESULTS}

\section{Preliminary and quantitative phytochemical screening}

The extraction yield of ethanol extract was found to be $9.6 \% \mathrm{w} / \mathrm{w}$. The extract was dark green in colour. The 
results of preliminary phytochemical analysis of ethanolic extract of $\mathrm{HH}$ indicated the positive result for all classes of secondary metabolites like alkaloids, anthocyanins, flavonoids, saponins, tannins, carbohydrates and proteins.

Then $H H$ extract was investigated for the total phenolic compounds, total flavonoid content and anthracyanin content using UV. The results of phenolic content by UV visible spectroscopy was expressed by mean \pm standard deviation. The quantitative phytochemical determination of ethanolic extract of $H H$ contains phenolics $(7.40 \pm 0.50 \mathrm{mg} / \mathrm{g})$, flavanoids $(3.50 \pm 0.85 \mathrm{mg} / \mathrm{g})$, anthocyanins $(18.53 \pm 1.10 \mathrm{mg} / \mathrm{g})$

\section{Wound healing activity}

The wound healing contracting ability of ethanolic extract of $H H$ of different concentrations by using oleaginous ointment base on excision wound, incision wound and burn wound models was significantly greater than that of the negative control group. The extract ointment treated groups showed significant wound healing from 3rd day onwards which was comparable to that of standard drug i.e. povidone iodine ointment treated group in all three wound models.

\section{Incision wound model}

The $20 \%$ extract of ointment treated groups showed significant tensile strength on 10th post wounding day was comparable with that of standard drug i.e. povidone iodine ointment treated group. The maximum tensile strength was observed in $(17.69 \pm 0.20) \mathrm{g}$ which almost similar to that of povidone iodine ointment treated group $(20.43 \pm 0.05) \mathrm{g}$. The 10\% extract group showed maximum tensile strength was observed in $(15.45 \pm 0.15) \mathrm{g}$ as shown in the Table I and Figure 1.

\section{Excision wound model}

The wound closure time was less, as the percentage of wound contraction was rapid with high dose of $\mathrm{HH}$

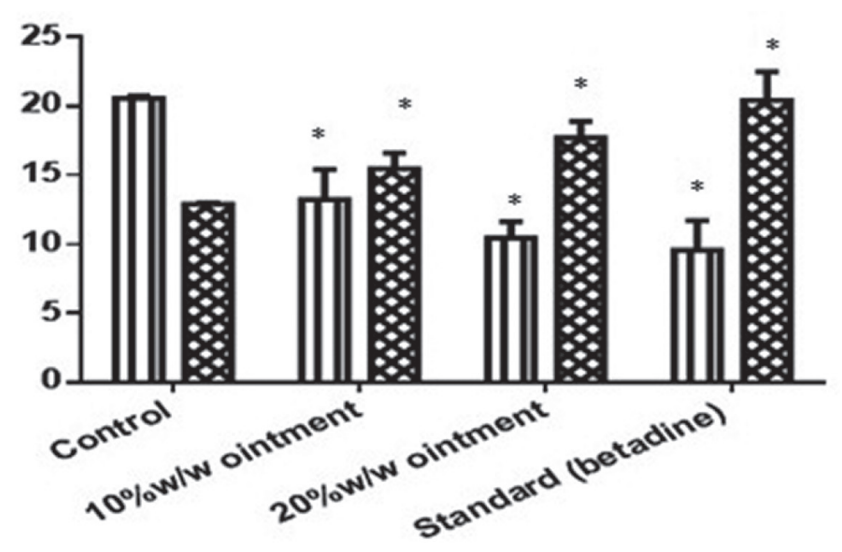

Treatment Groups

마 Epithelialisation period (Mean time in days)

... Tensile Strength $\left(\mathrm{g} / \mathrm{mm}^{2}\right)$ 10th day

FIGURE 1 - Measurement of epithelialisation and tensile strength in incision wound model.

and $20 \% \mathrm{w} / \mathrm{w}$ extract group exhibited $100 \%$ contraction in $(16.24 \pm 0.21)$ days during excision wound healing which is almost similar to that of povidone iodine ointment treated group $(15.91 \pm 0.12)$ days. The $10 \% \mathrm{w} / \mathrm{w}$ extract group of animals showed significant wound contraction from 6th day onwards and achieved $100 \%$ wound closure in $(20.8 \pm 0.23)$ days as shown in Table II and Figure 2 . The results of the present study revealed that both concentrations (20\% extract ointment and $10 \%$ extract ointment) of an ethanolic extract of $\mathrm{HH}$ have significant wound healing activity in excision model.

\section{Determination of hydroxyproline and hexosamine content}

The hexosamine and hydroxyproline content of granulation tissue of 4,8 and 16 post surgery days are indicated in Table III. A significant increase in the hydroxyproline content was observed in $\mathrm{HH}$ treated

TABLE I - Effect of topical application of ethanolic extract of Hibiscus hirtus on healing of incision wound model in rabbits

\begin{tabular}{lcc}
\hline Groups & $\begin{array}{c}\text { Epithelialisation period } \\
\text { (Mean time in days) }\end{array}$ & $\begin{array}{c}\text { Tensile Strength }\left(\mathbf{g} / \mathbf{m m}^{2}\right) \\
\mathbf{1 0}^{\text {th }} \mathbf{\text { day }}\end{array}$ \\
\hline Negative control & $20.58 \pm 0.16$ & $12.89 \pm 0.11$ \\
Ethanolic extract of $H$. hirtus $(10 \% \mathrm{w} / \mathrm{w}$ ointment) & $13.21 \pm 2.22^{*}$ & $15.45 \pm 1.15^{*}$ \\
Ethanolic extract of $H$. hirtus $(20 \% \mathrm{w} / \mathrm{w}$ ointment) & $10.45 \pm 1.19^{*}$ & $17.69 \pm 1.20^{*}$ \\
Standard (Povidone iodine ointment) & $9.56 \pm 2.15^{*}$ & $20.43 \pm 2.05^{*}$ \\
\hline
\end{tabular}

Values are expressed as mean $\pm \mathrm{SEM} ; \mathrm{n}=3$ animals in each group; ${ }^{*} p<0.05$. Statistically significant difference in comparison with negative control group. 
TABLE II - Effect of topical application of ethanolic extract of Hibiscus hirtus on healing of excision wound model

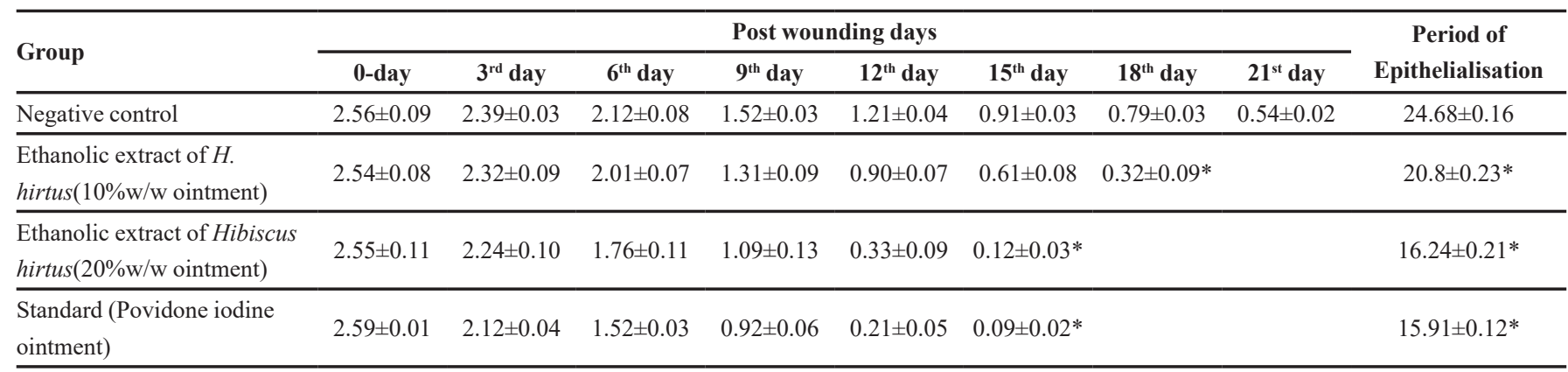

Values are expressed as mean $\pm \mathrm{SEM} ; \mathrm{n}=3$ animals in each group; ${ }^{*} p<0.05$. Statistically significant difference in comparison with negative control group.

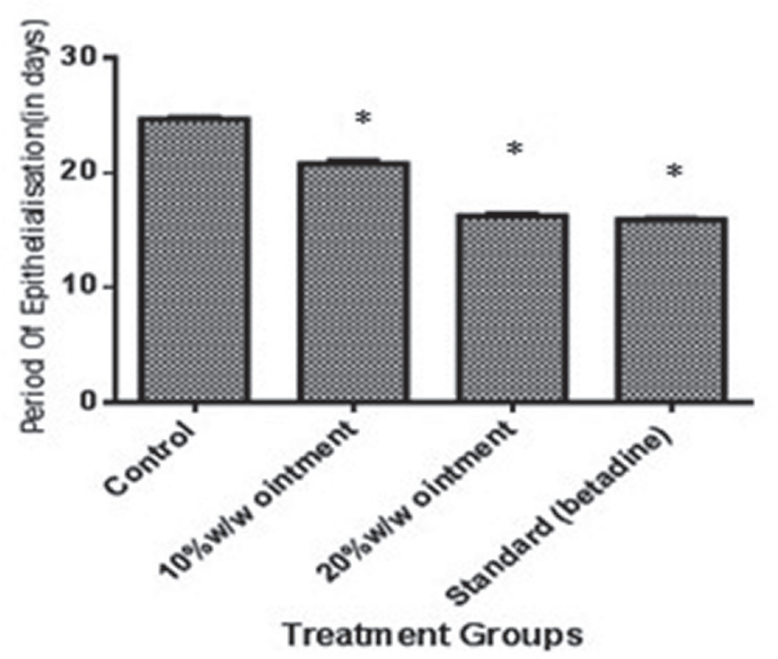

FIGURE 2 - Epithelialization Periods in different treatment groups in excision wound models.

groups than negative control groups. Throughout the healing course, hexosamine and hydroxyproline content were found to be increased in all treated groups compared to the negative control group, which are a very important constituent of the extracellular matrix for the healing process. These components are good markers for wound healing activity. The hydroxyproline and hexosamine content of granulation tissue of 4,8 and 16 post surgery days are given in Table III. A significant increase in the hydroxyproline content was observed in $H H$ treated groups than that of negative control groups. Throughout the course of healing, hydroxyproline and hexosamine content were found to be more in all treated groups than negative control group, which are important constituents of the extracellular matrix for healing. These compounds are good markers for wound healing.

\section{Burn wound model}

The percentage of wound contraction was greater with $20 \%$ dose of $H H$ and $100 \%$ wound contraction was observed in (14.4 \pm 0.89$)$ days, which almost similar to that of povidone iodine ointment treated group (13.67 \pm 0.38$)$ days. The low dose extract group of animals showed significant wound contraction from 6th day onwards and achieved $100 \%$ wound closure in $(18.7 \pm 0.22)$ days as shown in Table IV and Figure 3.

\section{Histopathalogical studies}

The granulation tissue provides further evidence

TABLE III - Hexosamine and hydroxyproline content of granulation on different days of healing

\begin{tabular}{lcccccc}
\hline \multirow{2}{*}{ Treatments } & \multicolumn{3}{c}{ Hexosamine (mg/100 mg of tissue) } & \multicolumn{2}{c}{ Hydroxyproline (mg/g tissue) } \\
\cline { 2 - 7 } & 4th day & 8th day & 16th day & 4th day & 8th day & 16th day \\
\hline Negative control & $0.24 \pm 0.30$ & $0.44 \pm 0.05$ & $0.65 \pm 0.08$ & $23.6 \pm 3.11$ & $31.5 \pm 1.08$ & $41.8 \pm 1.21$ \\
\hline $\begin{array}{l}\text { Ethanolic extract of } H \text {. hirtus } \\
(10 \% \text { w/w ointment })\end{array}$ & $0.31 \pm 0.03$ & $0.56 \pm 0.03$ & $0.66 \pm 0.02^{*}$ & $29.6 \pm 1.09$ & $44.8 \pm 2.15$ & $62.8 \pm 1.37^{*}$ \\
\hline $\begin{array}{l}\text { Ethanolic extract of } \text { H. hirtus } \\
(20 \% \text { w/w ointment })\end{array}$ & $0.42 \pm 0.03$ & $0.75 \pm 0.02$ & $0.81 \pm 0.01^{*}$ & $39.3 \pm 1.19$ & $53.8 \pm 2.15$ & $74.9 \pm 2.27^{*}$ \\
\hline Standard (Povidone iodine ointment) & $0.45 \pm 0.07$ & $0.83 \pm 0.04$ & $0.87 \pm 0.04^{*}$ & $43.4 \pm 1.09$ & $58.9 \pm 4.03$ & $81.8 \pm 2.17^{*}$ \\
\hline
\end{tabular}

Values are expressed as mean $\pm \mathrm{SEM} ; \mathrm{n}=3$ animals in each group $; * p<0.05$. Statistically significant difference in comparison with negative control group. 
TABLE IV - Effect of topical application of ethanolic extract of Hibiscus hirtus by using oleaginous ointment base for healing of burn wound model

\begin{tabular}{|c|c|c|c|c|c|c|c|c|c|}
\hline \multirow{2}{*}{ Group } & \multicolumn{8}{|c|}{ Post wounding days } & \multirow{2}{*}{$\begin{array}{c}\text { Period of } \\
\text { Epithelialisation }\end{array}$} \\
\hline & 0-day & $3^{\text {rd day }}$ & $6^{\text {th }}$ day & $9^{\text {th }}$ day & $12^{\text {th }}$ day & $15^{\text {th }}$ day & $18^{\text {th }}$ day & $21^{\text {st day }}$ & \\
\hline Negative control & $2.65 \pm 0.01$ & $2.57 \pm 0.01$ & $2.24 \pm 0.02$ & $1.95 \pm 0.01$ & $1.54 \pm 0.02$ & $0.89 \pm 0.02$ & $0.75 \pm 0.03$ & $0.54 \pm 0.01$ & $23.69 \pm 0.12$ \\
\hline $\begin{array}{l}\text { Ethanolic extract of } H \text {. hirtus } \\
(20 \% \mathrm{w} / \mathrm{w} \text { ointment })\end{array}$ & $2.63 \pm 0.10$ & $2.46 \pm 0.10$ & $1.93 \pm 0.09$ & $1.24 \pm 0.09$ & $0.25 \pm 0.01 *$ & & & & $14.4 \pm 0.89^{*}$ \\
\hline
\end{tabular}

Values are expressed as mean $\pm \mathrm{SEM} ; \mathrm{n}=3$ animals in each group; $* p<0.05$. Statistically significant difference in comparison with negative control group.

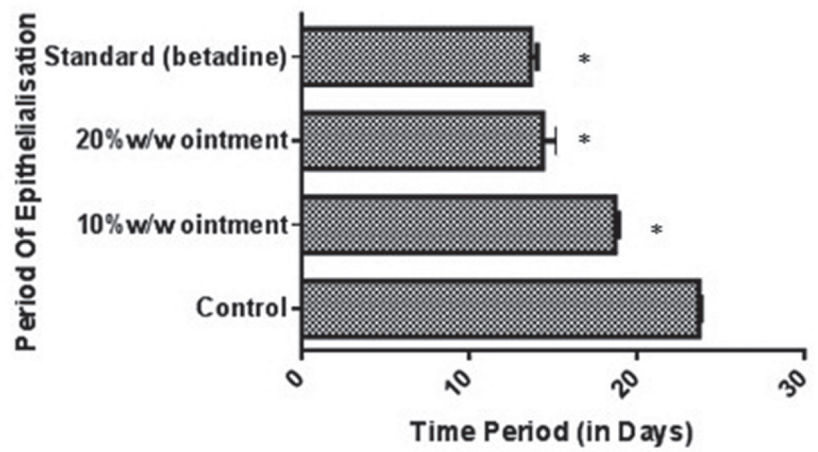

FIGURE 3 - Epithelialization Periods in different treatment groups in Burn wound models.

for the wound healing efficacy of the $H H$ extracts. The granulation tissue section of the negative control animals showed lower epithelialization and collagen formation with a greater macrophage aggregation indicating the incomplete wound healing (Figure 4.1). The sections of granulation tissue obtained from the $H H(10 \% \mathrm{w} / \mathrm{w}$ ointment) treated animals showed a significant rise in collagen deposition, a few macrophages and more fibroblasts (Figure 4.2). The high deposition of collagen and a significant decrease in infiltration of macrophage were observed in the wound tissue section treated with $\mathrm{HH}$ $(20 \% \mathrm{w} / \mathrm{w}$ ointment) (Figure 4.3$)$. The animals treated with povidone iodine ointment showed increased collagenation and depletion in the accumulation of macrophages at the site of the wound (Figure 4.4).

\section{Antimicrobial activity}

The whole plant extract of $H H$ has shown inhibition effects on the growth of all the organisms tested, but their efficiency in inhibitory was varied between the organisms. $H H$ has shown inhibition diameter from 12.4 to $18.3 \mathrm{~mm}$. Escherichia coli $(18.6 \pm 0.33 \mathrm{~mm})$ was most sensitive to $H H$ followed by Proteus mirabilis $(18.3 \pm 0.33 \mathrm{~mm})$,
Fig 4.1

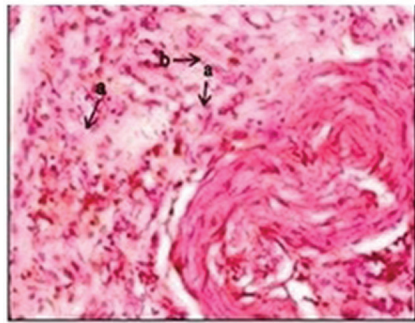

Fig 4.3

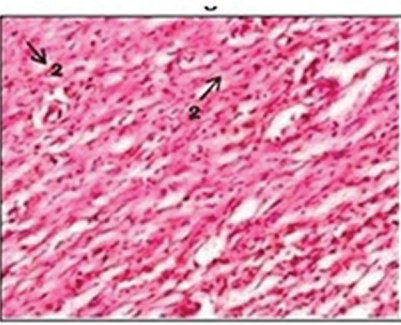

FIGURE 4 - Histological examination.

Bacillus subtilis (18.0 $\pm 0.57 \mathrm{~mm})$, Pseudomonas putida $(17.6 \pm 0.57 \mathrm{~mm})$, Klebesiella pneumonia $(17.0 \pm 0.57 \mathrm{~mm})$, Staphylococcus aureus (16.6 $\pm 0.33 \mathrm{~mm})$, Staphylococcus werneri $(16.3 \pm 0.33 \mathrm{~mm})$, Pseudomonas aerugenosa $(16.3 \pm 0.67 \mathrm{~mm})$ and Candida albicans $(14.2 \pm 0.12 \mathrm{~mm})$ . The antimicrobial activity results are indicated in Table $\mathrm{V}$ and Figure 5. The ethanolic extract of $H H$ has shown minimum inhibitory concentration at $125 \mathrm{mg} / \mathrm{mL}$ against gram negative organism Escherichia coli.

\section{DISCUSSION}

In terms of morbidity and mortality, wound represents as a major health problem. In the present investigation, three different models were used to assess the wound healing effect of $H H$ extracts on various phases of wound healing. So far no data have been reported on this plant product for wound healing property. The 
TABLE V - Zone of inhibition of ethanolic extract of Hibiscus hirtus

\begin{tabular}{|c|c|c|c|c|}
\hline Type of bacteria & Name of microorganism & & e of Inhibition (r & \\
\hline \multicolumn{2}{|c|}{ Antibacterial activity } & $\begin{array}{l}\text { Hibiscus hirtus } \\
(100 \mathrm{mg} / \mathrm{mL})\end{array}$ & $\begin{array}{c}\text { Hibiscus hirtus } \\
(200 \mathrm{mg} / \mathrm{mL})\end{array}$ & $\begin{array}{c}\text { Gentamycin } \\
(25 \mu \mathrm{g} / \mathrm{mL})\end{array}$ \\
\hline \multirow{3}{*}{ Gram positive bacteria } & Staphylococcus aureus & $15.0 \pm 0.88$ & $17.0 \pm 0.35^{*}$ & $19.0 \pm 0.58$ \\
\hline & Bacillus subtilis & $15.3 \pm 0.58$ & $17.0 \pm 0.57^{*}$ & $21.0 \pm 0.33$ \\
\hline & Staphylococcus Werneri & $14.4 \pm 0.58$ & $16.3 \pm 0.38^{*}$ & $20.0 \pm 0.45$ \\
\hline \multirow{5}{*}{ Gram negative bacteria } & Escherichia coli & $17.0 \pm 0.33$ & $19.0 \pm 0.41^{*}$ & $21.3 \pm 0.37$ \\
\hline & Klebesiella pneumonia & $14.5 \pm 0.45$ & $17.0 \pm 0.57 *$ & $18.0 \pm 0.53$ \\
\hline & Pseudomonas aerugenosa & $14.0 \pm 0.67$ & $16.3 \pm 0.67^{*}$ & $19.0 \pm 0.57$ \\
\hline & Pseudomonas putida & $14.3 \pm 0.36$ & $18.0 \pm 0.54 *$ & $19.0 \pm 0.58$ \\
\hline & Proteus mirabilis & $15.3 \pm 0.33$ & $18.0 \pm 0.39 *$ & $20.3 \pm 0.45$ \\
\hline \multicolumn{2}{|c|}{ Antifungal activity } & & & $\begin{array}{c}\text { Flucanozole } \\
(25 \mu \mathrm{g} / \mathrm{mL})\end{array}$ \\
\hline Fungal strain & Candida albicans & $12.4 \pm 0.15$ & $14.2 \pm 0.12 *$ & $17.4 \pm 0.21$ \\
\hline
\end{tabular}

Values are expressed as mean $\pm \mathrm{SEM} ; \mathrm{n}=3 ; * p<0.05$. Statistically significant difference in comparison with Standard group.

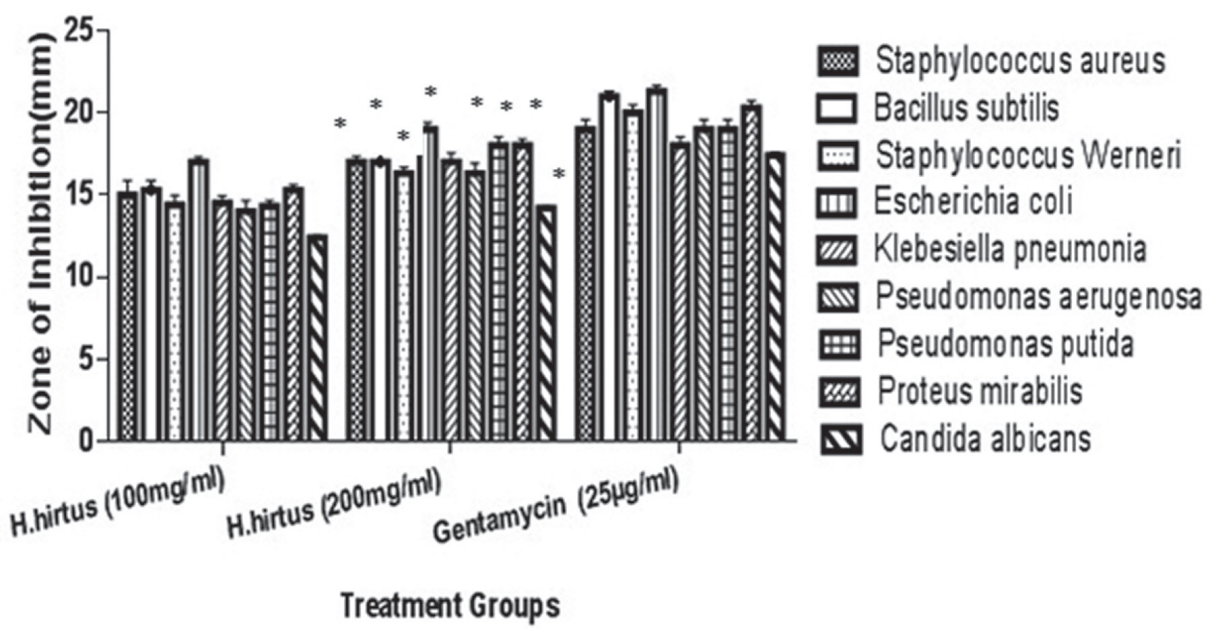

FIGURE 5 - Zone of inhibition of Hibiscus hirtus ethanolic extract.

main objective of wound healing is to heal the injury in the shortest time with minimal pain and discomfort to the patient. At the wound site, a flexible, fine scar with maximal tensile strength is desired. With the prepared ointments the wound was treated topically and observed that after the 4 th day, dead tissue was removed. The swelling and redness was minimized which indicates that the prepared ointment has tissue debrideeffect at the wound site after 8 days. "Kalka" (application of paste) is a major dosage form for wound healing located in muscle and included slough, according to Acharya Sushruta. Both functions like "Shodhana" (cleaning) and "Ropana" (healing) were made by the paste in DushtaVrana (Ajmeer et al., 2014). Kashaya rasa (astringent) which provides Lekhana (scraping) that helps to slough out necrosed tissue and preparing the wound for healing and helps to stop discharge from the wound. Madhura Rasa (sweet taste) gives nutrition to the wound tissue, which support in granulation tissue development (Dudhamal, Gupta, Bhuyan, 2010). Treatment of $H H$ extracts on wounded animals produce significant wound healing activity.

The wound healing is a complex process that involves the synchronization and activation of coagulatory and inflammatory events, epithelialization, fibrous tissue accretion, deposition of collagen, wound contraction, tissue granulation and remodeling (Ghosh, Gaba, 2013) Healing process occurs by immunological activities of victim itself, but various risk factors such as infection and week immunity may cause delay in healing has brought attention to promote this process (Kumar et al., 2008; 
Nayak, Anderson, Pereira, 2007). All the parameters that are discussed were significantly affecting wound healing activity of the whole plant. A significant antimicrobial activity has been observed. The components present in the crude extract are responsible for the significant antimicrobial activity. The contraction of the Wound indicates the reduction rate of the unhealed area during the process of healing. Thus, a fast wound contraction rate indicates better efficacy of medication.

Wound contraction plays an significant role in the full thickness wounds closure, where the surrounding skin is pulled in by forces that develop inside the granulation tissue (Ganeshkumar et al., 2012) Significant wound healing activity was produced by $H H$ treatment, which may be due to its angiogenic and mitogenic potential. Its prohealing activity was marked, as all the important parameters observed were affected significantly.

The healing tissue requires synthesis of collagen, which is a constituent of growing of the cell. Hydroxyproline concentration is a measure of collagen concentration. The faster rate of healing of the wound is due to higher concentration of hydroxyproline. Biochemical analysis revealed that increased hydroxyproline content, which is a reflection of raised proliferation of the cells and there by collagen synthesis gets increased (Trabucchi et al., 1985; Shukla, Rasik, Dhawan, 1999) In wound healing, type I collagen gene expression is found in every phase of the repair process (Mäkelä, Vuorio, 1985). The synthesis of collagen coincides with increased wound-breaking strength (Viljanto, Ojansuu, Keyworth, 1964). Ultimately, in wound healing, the rather acellular but fiber-rich scar tissue contains, predominantly, fibrils derived from collagen type I molecules (Cohen et al., 1992). Collagen type I can directly cause the migration and adhesion of numerous cell types, including keratinocytes and fibroblasts (Scharffetter-Kochanek et al., 1992). Increased hexosamine content reflects the stabilization of collagen molecules by enhancing electrostatic and ionic interactions (Nayak et al., 2009). Giving strength, integrity to the tissue matrix and plays an important role in homeostasis and in epithelialization at the latter phase of healing are attributed to collagen (Süntar et al., 2010)

Increased synthesis of hexosamine and hydroxyproline -treated rabbits provide strength to repair tissue and also healing pattern. The result indicates the potent wound healing capacity, which is evident from the contraction of the wound. Increased biochemical parameters and increased tensile strength in healing tissue have thus validated the ethnotherapeutic claim. The study revealed the effect of the $H H$ extract on collagen synthesis and their modulatory role in Col 1 a (I) gene expression which is a significant factor contributing to the normal wound healing process. $H H$ extract exhibited promising and somewhat better wound healing promoting activity similar to that of the standard povidone iodine ointment.

The study indicates a clear insight about the biochemical mechanisms responsible for the $\mathrm{HH}$ extract wound healing activity by using a rabbit model along with the significant antimicrobial activity provided pharmacological evidence to the ethnomedicinal claim. Preliminary phytochemical screening the of ethanolic extract of $H H$ revealed the presence of alkaloids, flavonoids, tannins, saponins, and carbohydrates. Broad spectrum of antibacterial activity was obtained by extracts of $H H$, which seemed to have beneficial effects on wound healing. $H H$ was found to show antibacterial activity against Escherichia coli, Proteus mirabilis, Bacillus subtilis, Pseudomonas putida, Klebesiella pneumonia, Staphylococcus aureus, Staphylococcus werneri, Pseudomonas aeruginosa and antifungal activity against Candida albicans.

Antimicrobial activity is one of the mechanisms by which some bioactive substance's effect wound healing, hence the investigation of the antibacterial potential of the extract in relation to gentamicin. Most infections on wounds are typically caused by common body bacteria flora (Gbedema et al., 2010). Pseudomonas aeroginosa and Echerichia coli, and Staphylococcus aureus were selected as they comprise the bacteria that commonly colonize open wounds to cause poor healing. The benefits of antimicrobials in wound management have been established in numerous studies suggesting accelerated healing with either systemic or topical application of antibiotics (Langford, Artemi, Benrimoj, 1997), thus, endorse antimicrobial activity as a mechanism of wound healing (Ofori-Kwakye et al. 2009; Mbosso et al., 2008; Mensah et al., 2006). The extract has an antibacterial effect against the selected organisms in this study suggesting that the wound healing activity of $\mathrm{HH}$ extract may be by an antibacterial activity mechanism.

Phytochemical tests are important in identifying new sources of therapeutically and industrially valuable compound having significance, to make the best use of natural wealth available. The results indicated that the extract contained alkaloids, anthocyanins, flavonoids, saponins, and tannins which are the main phytochemical groups with biological activities. Anthocyanins compounds have the healing properties. The anthocyanins have been found to be cardioprotective, hypocholesterolemic; antioxidative and hepatoprotective (Jonadet et al., 1990). They also have an antioxidant activity and inhibit low density lipoprotein (LDL) oxidation (Del Rio et al., 
2013). Alkaloids also interfere with cell division; hence the presence of alkaloids in the plant makes it a possible remedy in the treatment of cancer. Flavonoids are well known for their anti-viral, anti-inflammatory, antioxidant activity, cytotoxic and also used in the treatment of hypertension, diabetes, rheumatic fever (Usoh et al., 2005; Tolulope, 2007). In the present study, polyphenols were detected. Polyphenols have attracted a great attention in relation to their potential for beneficial effects on health. By blocking key enzymes at microbial metabolism tannins decrease the bacterial proliferation. It is clear that extract possesses good phytoconstituents that will be helpful in the future for the cure of different types of diseases.

\section{CONCLUSION}

Wound healing activity of our ethanolic extract of $H H$ has shown the good effect which has proved by different physical, histological, biochemical parameters. Even our plant has shown significant antimicrobial activity. It may be due to the presence of major active constituents present in our plant. From our preliminary studies we have confirmed that the activity is due to the presence of anthocyanins. Further studies are required to confirm the main active constituents responsible for the activity. The above results could justify the inclusion of the plant in the wound healing management in folk medicine.

\section{REFERENCES}

Aderounmua A, Omonisib A, Akingbasotec J, Makanjuolad M, Bejide R, Orafidiya L, et al. Wound-healing and potential antikeloidal properties of the latex of Calotropis procera (Aiton) Asclepiadaceae in rabbits. Afr J Tradit Complement Altern Med. 2013; 10(3):574-579.

Agarwal P, Singh A, Gaurav K, Goel S, Khanna H, Goel R. Evaluation of wound healing activity of extracts of plantain banana (Musa sapientum var. paradisiaca) in rats. Indian J Exp Biol. 2009;47(1):32-40.

Ajmeer AS, Dudhamal TS, Gupta SK, Mahanta V. Katupila (Securinega leucopyrus) as a potential option for diabetic wound management. J Ayurveda Integrat Med. 2014;5(1):60-63.

Bhaskar A, Nithya V. Evaluation of the wound-healing activity of Hibiscus rosa sinensis L (Malvaceae) in Wistar albino rats. Indian J Pharmacol. 2012;44(6):694-698.
Boateng JS, Matthews KH, Stevens HNE, Eccleston GM. Wound healing dressings and drug delivery systems: a review. J Pharm Sci. 2008;97(8):2892-2923.

Česonienė L, Daubaras R, Viškelis P, Šarkinas A. Determination of the total phenolic and anthocyanin contents and antimicrobial activity of Viburnum opulus fruit juice. Plant Foods Human Nutr. 2012;67(3):256-61.

Chang CC, Yang MH, Wen HM, Chern JC. Estimation of total flavonoid content in propolis by two complementary colorimetric methods. J Food Drug Analysis. 2002;10(3):178182.

Chen CC, Hsu JD, Wang SF. Hibiscus sabdariffa extract inhibits the development of atherosclerosis in cholesterol-fed rabbits. J Agric Food Chem. 2003;51(18):5472-5477.

Cohen IK, Die-gelmann RF, Lindblad WJ, Hugo NE. Wound healing: Biochemical and clinical aspects. Plastic Reconstruct Surg. 1992;90(5):926.

Del Rio D, Rodriguez-Mateos A, Spencer JP, Tognolini M, Borges G, Crozier A, et al. Dietary (poly) phenolics in human health: structures, bioavailability, and evidence of protective effects against chronic diseases. Antioxid Redox Signal. 2013;18(14):1818-1892.

Dudhamal T, Gupta S, Bhuyan C. Role of honey (Madhu) in the management of wounds (Dushta Vrana). Int J Ayurveda Res. 2010;1(4):271-273.

Ganeshkumar M, Ponrasu T, Krithika R, Iyappan K, Gayathri VS, Suguna L, et al. Topical application of Acalypha indica accelerates rat cutaneous wound healing by up-regulating the expression of type I and III collagen. J Ethnopharmacol. 2012;142(1):14-22.

Gbedema SY, Emelia K, Francis A, Kofi A, Eric W. Wound healing properties and kill kinetics of Clerodendron splendens G. Don, a Ghanaian wound healing plant. Pharmacogn Res. 2010;2(2):63-68.

Ghosh PK, Gaba A. Phyto-extracts in wound healing. J Pharm Pharm Sci. 2013;16(5):760-820.

Ghosh S, Samanta A, Mandal B, Bannerjee S, Chattopadhyay D. Evaluation of the wound healing activity of methanol extract of Pedilanthus tithymaloides (L.) Poit leaf and its isolated active constituents in topical formulation. J Ethnopharmacol. 2012;142(3):714-722. 
Harding KG, Moore K, Phillips TJ. Wound chronicity and fibroblast senescence-implications for treatment. Int Wound J. 2005;2(4):364-368.

Harish B, Krishna V, Kumar HS, Ahamed BK, Sharath R, Swamy HK et al. Wound healing activity and docking of glycogen-synthase-kinase-3- $\beta$-protein with isolated triterpenoid lupeol in rats. Phytomedicine. 2008;15(9):763-767.

Indian Pharmacopoeia, vol-II, the Controller of Publications, New Delhi; 1996.

Johansen PG, Marshall R, Neuberger A. Carbohydrates in protein. 2 . The hexose, hexosamine, acetyl and amide-nitrogen content of hen's-egg albumin. Biochem J. 1960;77(2):239-247.

Jonadet M, Bastide J, Bastide P, Boyer B, Carnat A, Lamaison $\mathrm{J}$, et al. In vitro enzyme inhibitory and in vivo cardioprotective activities of Hibiscus (Hibiscus sabdariffa L.). J Pharm Belgique. 1990;45(2):120-124.

Kamboj V. Herbal medicine. Curr Sci-Bangalore. 2000;78(1):3538.

Khan IA, AzizA, Sattar M, Munawar S H, Manzoor Z, Raza MA, Fatima G, Hannan A, et al. Evaluation of wound healing potential of Rumex vesicarius L. Leaf extract and fractions in rabbit. Afr J Tradit Complement Alternat Med. 2015;12(2):60-64.

Khandelwal KR. Practical pharmacognosy. Pragati Books Pvt. Ltd.; 2008.

Khandelwal K. Practical Pharmacognosy Techniques and Experiments. 11 ed. Pune: Nirali Prakashan; 2004. 149-56 p.

Kumar MS, Kirubanandan S, Sripriya R, Sehgal PK. Triphala promotes healing of infected full-thickness dermal wound. J Surgical Res. 2008;144(1):94-101.

Langford JH, Artemi P, Benrimoj SI. Topical antimicrobial prophylaxis in minor wounds. Ann Pharmacother. 1997;31(5):559-563.

Lee K. Studies on the mechanism of action of salicylates III. Effect of vitamin A on the wound healing retardation action of aspirin. J Pharm Sci. 1968;57(7):1238-1240.

Lingaraju G, Krishna V, Joy Hoskeri H, Pradeepa K, Venkatesh, Babu PS, et al. Wound healing promoting activity of stem bark extract of Semecarpus anacardium using rats. Nat Product Res. 2012;26(24):2344-2347.
Mäkelä J, Vuorio E. Type I collagen messenger RNA levels in experimental granulation tissue and silicosis in rats. Med Biol.1985;64(1):15-22.

Mbosso EJT, Ngouela S, Nguedia JCA, Beng VP, Rohmer M, Tsamo E. Spathoside, a cerebroside and other antibacterial constituents of the stem bark of Spathodea campanulata. Nat Prod Res. 2008;22(4):296-304.

Menke NB, Ward KR, Witten TM, Bonchev DG, Diegelmann RF. Impaired wound healing. Clin Dermatol. 2007;25(1):19-25.

Mensah AY, Houghton PJ, Dickson RA, Fleischer TC, Heinrich $\mathrm{M}$, Bremner $\mathrm{P}$, et al. In vitro evaluation of effects of two Ghanaian plants relevant to wound healing. Phytother Res. 2006;20(11):941-944.

Mohamed R, Fernandez J, Pineda M, Aguilar M. Roselle (Hibiscus sabdariffa) seed oil is a rich source of $\gamma$ tocopherol. J Food Sci. 2007;72(3):S207-S211

Murphy PS, Evans GR. Advances in wound healing: a review of current wound healing products. Plastic Surgery Int. 2012;2012:190436.

Nakae H, Inaba H. Effectiveness of electrolyzed oxidized water irrigation in a burn-wound infection model. J Trauma Acute Care Surgery. 2000;49(3):511-514.

Nayak B, Anderson M, Pereira LP. Evaluation of wound-healing potential of Catharanthus roseus leaf extract in rats. Fitoterapia. 2007;78(7):540-544.

Nayak BS, Raju SS, Eversley M, Ramsubhag A. Evaluation of wound healing activity of Lantana camara L. - a preclinical study. Phytother Res. 2009;23(2):241-245.

Ofori-Kwakye K, Kwapong A, Adu F. Antimicrobial activity of extracts and topical products of the stem bark of Spathodea campanulata for wound healing. Afr J Tradit Complementa Altern Med. 2009;6(2):168-74.

Rashed A, Afifi F, Disi A. Simple evaluation of the wound healing activity of a crude extract of Portulaca oleracea L.(growing in Jordan) in Mus musculus JVI-1. J Ethnopharmacol. 2003;88(2):131-136

Scharffetter-Kochanek K, Klein CE, Heinen G, et al. Migration of a human keratinocyte cell line (HACAT) to interstitial collagen Type I Is mediated by the $\alpha 2 \beta$ 1-Integrin receptor. J Investig Dermatol. 1992;98(1):3-11. 
Sharath R, Harish B, Krishna V, Sathyanarayana B, Swamy H. Wound healing and protease inhibition activity of Bacoside-A, isolated from Bacopa monnieri wettest. Phytother Res. 2010;24(8):1217-1222.

Sharma A, Bhardwaj S, Mann A, Jain A, Kharya M. Phcog Rev.: Review article screening methods of antioxidant activity: an overview. Pharmacogn Rev. 2007;1(2).

Shukla A, Rasik AM, Dhawan BN. Asiaticoside-induced elevation of antioxidant levels in healing wounds. Phytother Res. 1999;13(1):50-54.

Sidhu GS, Mani H, Gaddipati JP, Singh AK, Seth P, Banaudha $\mathrm{KK}$, et al. Curcumin enhances wound healing in streptozotocin induced diabetic rats and genetically diabetic mice. Wound Repair Regen. 1999;7(5):362-374.

Sidram AN, Lokapure SG, Kalyane N. Study on anti-solar activity of ethanolic extract of flower of Hibiscus Rosa-sinensis Linn. Res J Pharm Technol. 2011;4(3):472-473.

Singleton VL, Orthofer R, Lamuela-Raventós RM. Analysis of total phenols and other oxidation substrates and antioxidants by means of folin-ciocalteu reagent. Methods Enzymol. 1999;299:152-178.

Süntar IP, Akkol EK, Yılmazer D, Baykal T, Kirmizibekmez H, Alper M, Yeşilada E. Investigations on the in vivo wound healing potential of Hypericum perforatum L. J Ethnopharmacol. 2010;127(2):468-477.
Swamy HK, Krishna V, Shankarmurthy K, Abdul Rahiman B, Mankani KL, Mahadevan KM, et al. Wound healing activity of embelin isolated from the ethanol extract of leaves of Embelia ribes Burm. J Ethnopharmacol. 2007;109(3):529-534.

Tolulope M. Cytotoxicity and antibacterial activity of methanolic extract of Hibiscus sabdariffa. J Med Plants Res. 2007;1(1):9-013.

Trabucchi E, Preis BF, Baratti C, Montorsi W. Topical treatment of experimental skin lesions in rats: macroscopic, microscopic and scanning electron-microscopic evaluation of the healing process. Int J Tissue React. 1985;8(6):533-544.

Usoh I, Akpan E, Etim E, Farombi E. Antioxidant actions of dried flower extracts of Hibiscus sabdariffa L. on sodium arseniteinduced oxidative stress in rats. Pak J Nutri. 2005;4(3):135-141.

Varoglu E, Seven B, Gumustekin K, Aktas O, Sahin A, Dane $\mathrm{S}$, et al. The effects of vitamin e and selenium on blood flow to experimental skin burns in rats using the $133 \mathrm{Xe}$ clearance technique. Open Med. 2010;5(2):219-223.

Viljanto J, Ojansuu P, Keyworth L. Biochemical basis of tensile strength in wound healing: an experimental study with viscose cellulose sponges on rats. Polytypos; 1964.

Woessner JF. The determination of hydroxyproline in tissue and protein samples containing small proportions of this imino acid. Arch Biochem Biophys. 1961;93(2):440-447.

Received for publication on $10^{\text {th }}$ March 2017 Accepted for publication on $12^{\text {th }}$ June 2018 